\title{
継目無鋼管の曲り矯正制御*
}

\author{
加藤 高 明*1, 浦 田 暎三*2 \\ 中西実*3, 山崎一男*4
}

\section{Control for Straightening Process of Seamless Pipe}

\author{
Takaaki KATOH, Eizo URATA, \\ Minoru NAKANISHI, and Kazuo YAMAZAKI
}

\begin{abstract}
Seamless pipes have some terminal end bends which must be cured before shipment. This paper describes a real-time control system for a press straightening process. The straightening process must account for elastic springback, which is a strong function of the material properties of the pipe. On-line measurements of reactive force and deflection of the pipe during the early part of the bending process are performed to form an elastic-plastic model in a microcomputer. The final correct die position to yield the desired unloaded shape is predicted using the elastic-plastic model. Through a series of experiments on different materials and different sizes and shapes, the straightening process gave an accuracy of $0.18 \mathrm{~mm} / \mathrm{m}$, which is sufficiently smaller than product allowances.
\end{abstract}

Key Words: Press Working, Computer Control, Fluid Power Systems, Elastic-Plastic Model, Observer, Straightening, Seamless Pipe

\section{1. 綪}

油井管、ガス管の高深度化，寒冷地化等の傾向に伴 い、継目無鋼管の品質向上に対する要求が厳しくなっ ている、一般の製造プロセスでは管端部 $1 \mathrm{~m}$ につき数 $\mathrm{mm}$ 程度の曲りが生じるのでこれを出荷前に 0.5〜1.0 mm 以内に矯正しなけ机ばならない. 精密な ものではこれ以上の真直度が要求される。そのため， 鋼管管端部の曲り矯正在高能率，高精度に行う必要が ある。ところが，曲げ加工では除荷後にスプリングバ ックがあるため、スプリングバックをあらかじめ兒込 んで余計に曲げなければならない。このスナリングバ ック量は肉厚あるいは加丁条件によっても異なるた ぬ，曲げモーメントの理論值に上る方法では矯正精度 が問題となる。また試し曲げによる計測值を用いる方 法では能率が良くない(1)。

そこで，本論文では，真直度の高い鋼管を能率良く

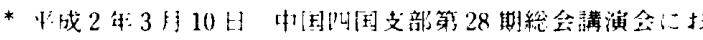

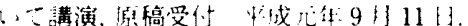

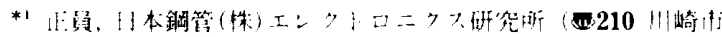

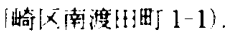

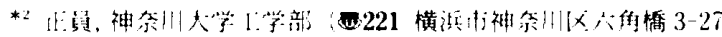
$-1)$

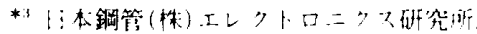

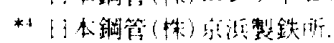

得るために，材料特性（材質，外径，肉厚，縦弾性係数， 曲げ半径扔よび加工条件など）に依存せずスプリング バックを補償した自動矯正制御方法について考察し た。この方法は鋼管の曲げ加工中に鋼管にかかる力と 変位をリアルタイムで計測し，スプリングバック量を 推定する方式（オブザーバ）であるため，材料特性をあ らかじめデータとして保持したり，スプリングバック 量を実験的に求めて学習するような複雑な手続きを必 要としないものである。このような適応曲げ制御方法 については，薄板では多くの研究があるが(2)-(4)，鋼管 の例は少ない。

電気一油压サーボ機構による200トン油圧プレスを 用いて、6 種類の鋼管 (STKM13A およびSTO-J)に 対して, 目標矯正変位を $0.1 \sim 2.0 \mathrm{~mm}$ として実験を 行った。その結果, $0.18 \mathrm{~mm}$ 以内の精度ですべて矯正 することができたので，本制御方法の有効性を実証す ることができた。

\section{2. 曲げ稫正制御方法}

薄肉户筒形断面形状をもつ継目無鋼管の曲げ矯正は 図1に示す上うに支持点間の中央位置に集中荷重 $F$ 受ける単純支持ばりの形式で行う（図1に扔いて， $\ell$ : 支持点間距離, $d_{0}$ : 外径, $d_{i}$ : 内径, $t$ : 肉厚, 
$\delta_{r}$ ：目標矯正変位).このとき, 荷重 $F$-変位 $\delta$ 曲線は, 図 2 に示すような特性を持つため, 除荷時にスプリン グバック $\delta_{s}$ を生じる $\left(F_{m}\right.$ ：目標制御変位に達した時 の荷重, $F_{e}$ : 降伏荷重).そこで,リアルタイムでスプ リングバック量 $\delta^{*}$ を推定し，精度良く矯正曲げを行 う制御方式を考案したので，以下に示す。

図 1(a)の位置に集中荷重 $F$ を受ける単純支持ば りの基礎式は, 次のようになる（E：縦弹性係数

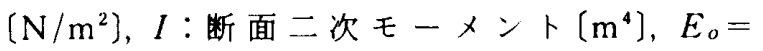
$\left.48 E I / \ell^{3}(\mathrm{~N} / \mathrm{m})\right)$.

$$
\delta=F / E_{o}
$$

図 2 の $F-\delta$ 曲線の傾きは，後の実験例（図 8,9参 照）に示すように, 負荷時においても除荷時において もほ济平行とみなせ， $E_{o} \doteqdot E_{o}^{\prime}$ となる。この性質を利用 して，第一に $E_{o}^{\prime}$ の推定を行う. まず負荷を与え, 降伏 に至る手前の時点の 2 点の荷重㧈よび変位 $\left(F_{1}, \delta_{1}\right)$, $\left(F_{2}, \delta_{2}\right)$ を計測する.そしてこの 2 点を基に直線近似 すれば， $E_{o}^{\prime} \doteqdot\left(F_{2}-F_{1}\right) /\left(\delta_{2}-\delta_{1}\right)$ が求められる。このと き 2 点より多い点を選んで最小二乗近似しても良い.

次に, $E_{\circ}^{\prime}$ を推定した後は，常時荷重および変位 $\left(F_{n}, \delta_{n}\right)$ を計測してその時点で除荷した場合の永久変 位 $\delta$ を次のようにして求める。

$$
\begin{aligned}
& \delta^{*}=F_{n} / E_{o}^{\prime} \\
& \bar{\delta}=\delta_{n}-\delta^{*}
\end{aligned}
$$

そして目標永久変位 $\delta_{r}$ と推定永久変位 $\delta$ との差を
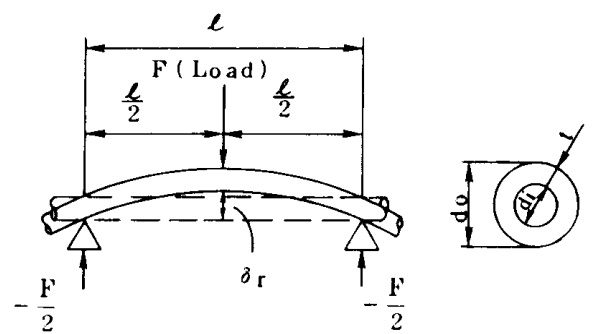

(a) 正面図

(b) 側面図

図 1 鋼管の曲げ嬌正モデル図

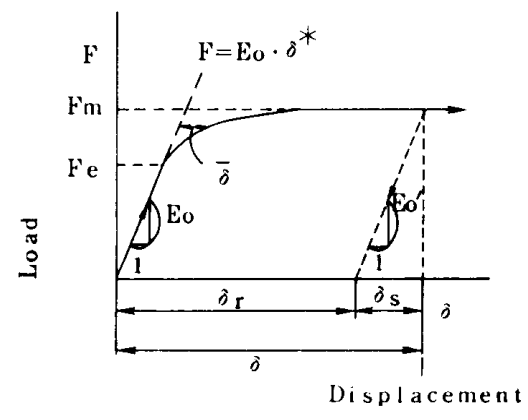

図 2 荷重 $F$-ひずみ（変位） $\delta$ 曲線
とり，正であれば負荷を継続し，負であれば除荷する。 以上に述べた手順をフローシートにまとめると図 3 の ようになる。

\section{3. 油圧シリンタの制御}

$3 \cdot 1$ 基礎式およひ制御系の説明 考察する系の 油圧制御部を図 4 に示す。サーボ弁からの流量は $i>0$ のとき

$$
Q_{1}=K_{v} i \sqrt{P_{s}-P_{1}}, Q_{2}=K_{v} i \sqrt{P_{2}} \cdots
$$

$i<0$ のとき,

$$
Q_{1}=K_{v} i \sqrt{P_{1}}, Q_{2}=K_{v} i \sqrt{P_{s}-P_{2}}
$$

である。ただし， $i$ : 電流, $K_{v}$ : 流量に関する定数, $P_{s}$ : 供給圧力, $P_{1}, P_{2}:$ シリンダ内圧力, $Q_{1}, Q_{2}:$ シリ

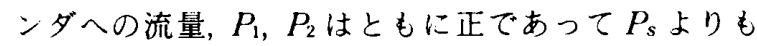
小さいと仮定する。この曲げ矯正制御は，シリンダに 対し鋼管からの負荷反力がかかる系となるため，油が 十分圧縮されてから矯正される。また，矯正変位は微 小であり，F- $\delta$ 曲線を監視しながらゆっくり曲げる ため微速制御で行われることになる。これらのことか ら，弁の動特性や油の圧縮性は無視できる.そこで、シ リンダ室での連続の式は,

$$
Q_{1}-A_{1} v=0, Q_{2}-A_{2} v=0
$$

となる $\left(A_{1}, A_{2}\right.$ : ピストンの受圧面積 $v:$ 速度). ピス トンの運動方程式は,

$$
M \frac{d v}{d t}-M g+\operatorname{sgn}(v) \cdot F_{c}+F=A_{1} P_{1}-A_{2} P_{2}
$$

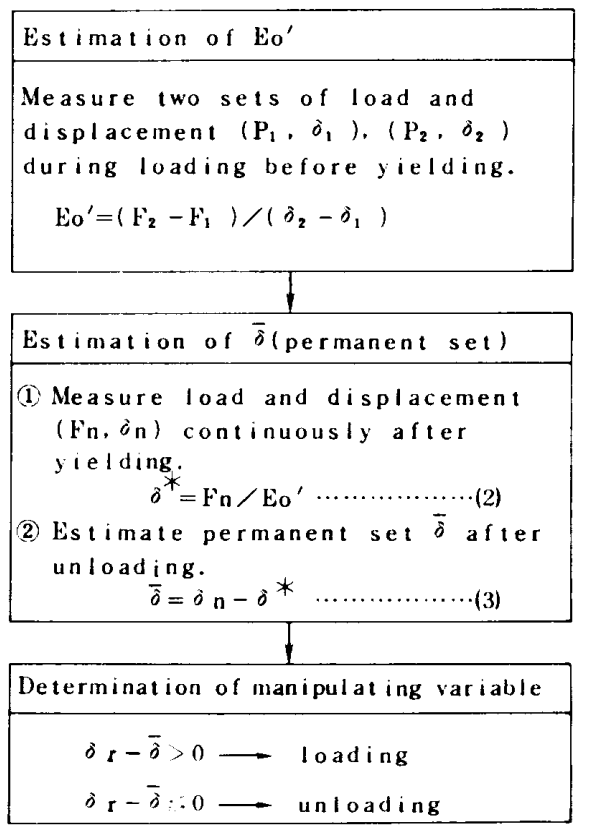

図 3 曲げ矮正制御方法の概略 


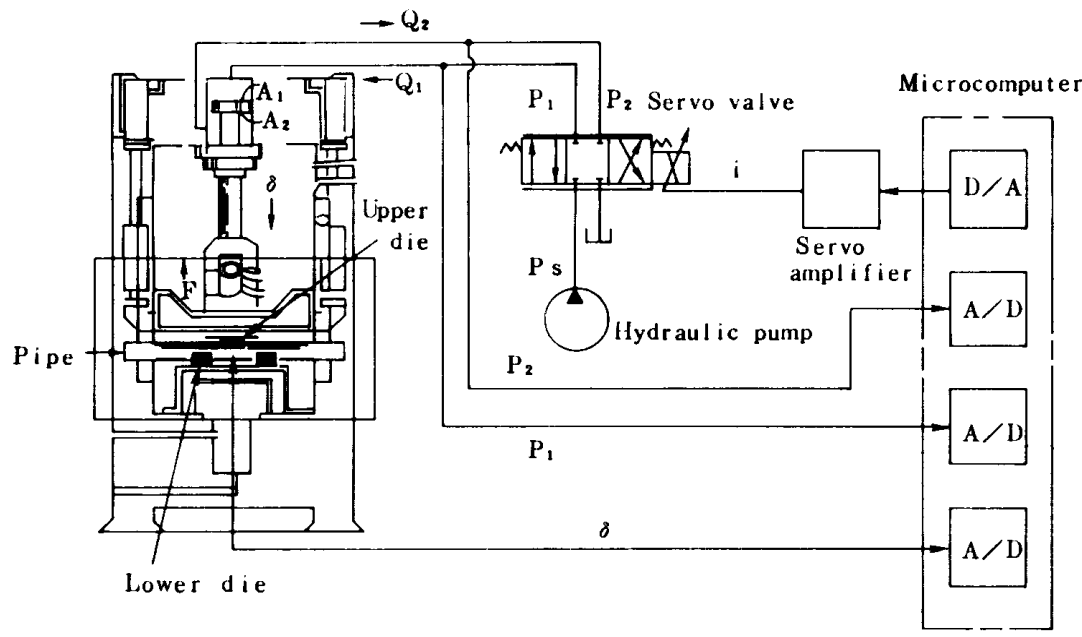

図 4 制御システムの䊤成

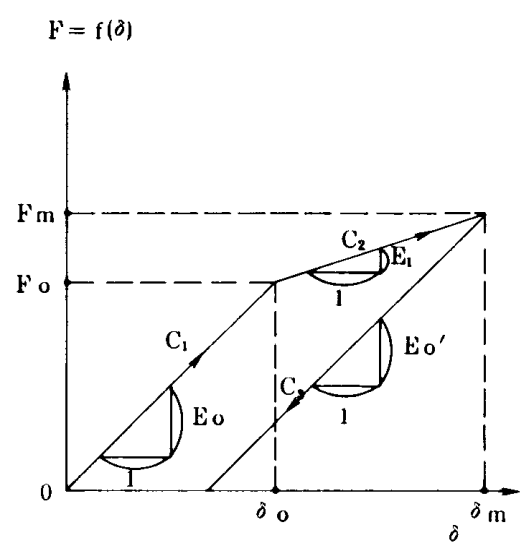

図 5 ヒステリシスのある負荷特性

である（F：クーロン摩擦， $g$ : 重力加速度, $M$ : 質

量).ピストン変位を $\delta$ とすると,

$d \delta / d t=v$

である，Fはピストンにかかる荷重で, パイプを曲げ るのに要する力の反力である。

図 5 は図 2 の変形プロセスを折れ線で近似したもの で, 線分 $\mathrm{C}_{1}, \mathrm{C}_{2}$ 注変形の増加プロセスを, $\mathrm{C}_{3}$ では除 荷による変形隇少プロセスを表す。折れ点を $\delta_{o}, F_{o}$ ， このときの時刻を $t_{o}$ とすると，

(i ) $0<\delta<\delta_{o}$ で, $d \delta / d t>0$ のときは, $F=E_{o} \delta$ $\cdot(9 \cdot a)$

(ii) $\delta>\delta_{o}$ で, $d \delta / d t>0$ のときは, $F=F_{o}+E_{1}\left(\delta-\delta_{o}\right)$

(iii) $\delta>\delta_{o}$ で, $d \delta / d t<00$ ときは,

$F=F_{o}+E_{1}\left(\delta_{m}-\delta_{o}\right)+E_{o}\left(\delta-\delta_{m}\right)$ である。

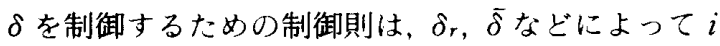
を決定するものである，比例補償では，偏差と制御量 が比例するから目標值に近づくと速度が遅くなって制 御に時間がかかってしまう。また，途中で制御をやめ てしまうとオフセットが残ってしまう。 そのため,こ のような比例補償のもつ問題点を解消し，これに変わ るもっとも簡単な制御則として以下のものを考えた。

$$
\begin{aligned}
& i=I \quad\left(\delta_{r}-\bar{\delta}>0\right) \\
& \left.i=-I \quad\left(\delta_{r}-\bar{\delta} \leqq 0\right),(I: \text { 定数 })\right\} \\
& \bar{\delta}=\delta-F / E_{o} \ldots \ldots \ldots \ldots \ldots \ldots \ldots \ldots \ldots \ldots \ldots \ldots \ldots \ldots \ldots \ldots \ldots \ldots
\end{aligned}
$$

式( 4$) \sim(6)$ から, $i>0$ では,

$$
\left.\begin{array}{l}
P_{1}=P_{s}-\left(\frac{A_{1}}{K_{v} i}\right)^{2} v^{2}, P_{2}=\left(\frac{A_{2}}{K_{v} i}\right) v^{2} \\
i<0 \text { では, } \\
P_{1}=\left(\frac{A_{1}}{K_{v} i}\right)^{2} v^{2}, P_{2}=P_{s}-\left(\frac{A_{2}}{K_{v} i}\right)^{2} v^{2}
\end{array}\right\}
$$

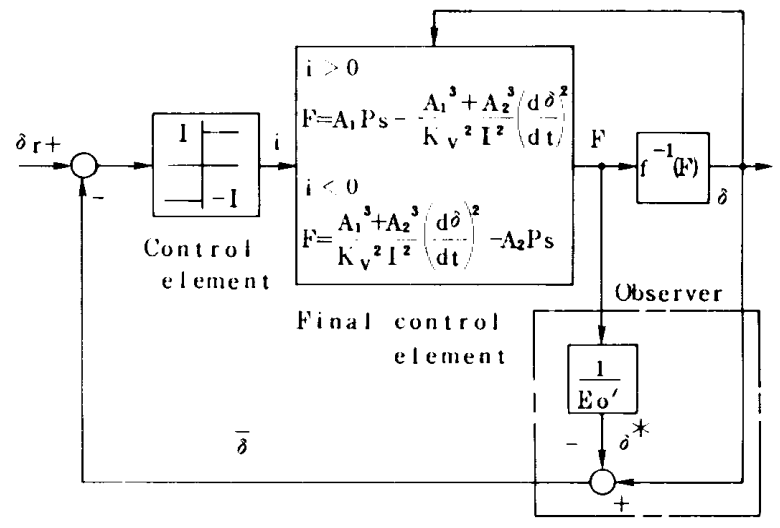

図 6 制御系のブロック線図

である。負荷が十分大きい場合 $(|F|>\mid M d v / d t$ - $\left.M g \pm F_{c} \mid\right)$ を考えると,

$$
F \doteqdot f(\delta)=A_{1} P_{1}-A_{2} P_{2}, \delta=f^{-1}(F)
$$

と書くことができる。制御系のブロック図を簡略化し て示すと、戍6のようになる。

$3 \cdot 2$ ピストンの变位 始めにシステムは静止状 態にあり， $\delta=0, i=0$ であったとする. $t=0$ で入力 $\delta_{r}$ を加えたとする $\left[\delta_{r}=a U(t): U(t)\right.$ : 単位ステッフ関 数].

(i ) $0<\delta<\delta_{o}$ かつ $d \delta / d t>0$ のとき，この区間で は $\bar{\delta}=0$ であるから，式(9・a)，(12)，(13)により，i =Iであって,

$$
\frac{d \delta}{d t}=K_{v} I \sqrt{\frac{A_{1} P_{s}}{A_{1}^{3}+A_{2}{ }^{3}}} \sqrt{1-\frac{E_{o} \delta}{A_{1} P_{s}}}
$$

この微分方程式を解くと, $\delta=\delta_{o}$ となる時刻 $t_{o}$ は

$$
t_{o}=\frac{2}{\alpha} \cdot \frac{x_{o}}{1+\sqrt{1-x_{o}}}, x_{o}=-\frac{E_{o} \delta}{A_{1} P_{s}}
$$

である、ただし、 
$\alpha=\frac{K_{v} I E_{o}}{A_{1} P_{s}} \sqrt{\frac{A_{1} P_{s}}{A_{1}^{3}+A_{2}^{3}}}, x=\frac{E_{o} \delta}{A_{1} P_{s}}$ とする.

(ii) $\delta>\delta_{o}$ では， $\bar{\delta} \neq 0$ である.すなわち，式(10・ b) をブロック線図中の式に代入すると， $t>t_{o}$ では次 式を得る.

$$
\begin{aligned}
\frac{d \delta}{d t} & =K_{v} I \sqrt{\frac{A_{1} P_{s}}{A_{1}{ }^{3}+A_{2}{ }^{3}}} \\
& \times \sqrt{1-\frac{E_{o} \delta_{o}}{A_{1} P_{s}}-\frac{E_{1}}{A_{1} P_{s}}\left(\delta-\delta_{o}\right)}
\end{aligned}
$$

$\delta$ が増加すると, やがて, $\bar{\delta}=a$ に達する，その時刻 などは次のように求められる，式 $(9 \cdot b) ，(11) に よ り ，$ このときの変位 $\delta_{m}$ および反力 $F_{m}, \delta_{m}$ となるまでの 時刻を $t_{m}$ とすると,

$$
\begin{aligned}
& a=\left(\delta_{m}-\delta_{o}\right)\left(1-E_{1} / E_{o}\right) \cdots \cdots \cdots \cdots \cdots \cdots \cdots \cdots \cdots \\
& \delta_{m}=\delta_{o}+\frac{a}{1-E_{1} / E_{o}}, F_{m}=E_{1}\left(\delta_{m}-\delta_{o}\right)+F_{o}
\end{aligned}
$$

$$
\begin{aligned}
t_{m} & =t_{o}+\frac{2 E_{o}}{\alpha E_{1}} \\
& \times\left\{\sqrt{1-x_{o}}-\sqrt{1-x_{m}-\left(E_{1} / E_{o}\right)\left(x_{m}-x_{o}\right)}\right\}, \\
x_{m} & =x_{o}+\frac{E_{o} a}{A_{1} P_{s}} \cdot \frac{1}{1-E_{1} / E_{o}}
\end{aligned}
$$

である。

(iii) $\bar{\delta}=\delta_{r}$ に達すると $i<0$ とかる.したがつて,

$$
\begin{gathered}
\frac{d \delta}{d t}=-\frac{K_{v} I}{\sqrt{A_{1}{ }^{3}+A_{2}{ }^{3}}} \sqrt{P_{s} A_{2}+E_{o} \delta-F_{m}} \\
F=\frac{A_{1}{ }^{3}+A_{2}{ }^{3}}{K_{v}{ }^{2} \bar{I}^{2}} \cdot\left(\frac{d \delta}{d t}\right)^{2}-A_{2} P_{s}=0 \cdots \cdots
\end{gathered}
$$

になると, ピストンは加工物から㒕机るから, 反力は 雾となる。このとき， $F=0$ であり， $\delta$ の值を $\delta_{t}$, 時刻 をたをとすると, 式 $(9 \cdot c)$ おび(20)から次式を得る。

$$
\delta_{t}=\left(1-E_{1} / E_{o}\right)\left(\delta_{m}-\delta_{o}\right) \text {. }
$$

よって式(17)により， $\delta_{t}=a$ になる。すなわち，ピスト ンが離れるときに, 部材には大きさ $a$ の残留変位が生
じている。その時刻は，

$$
\begin{gathered}
\alpha\left(t_{t}-t_{m}\right)=2\left\{\sqrt{\frac{A_{2}}{A_{1}}+x_{m}-\frac{F_{m}}{A_{1} \bar{P}_{s}}}\right. \\
\left.-\sqrt{\frac{A_{2}}{A_{1}}+x_{t}-\frac{F_{m}}{A_{1} P_{s}}}\right\} \cdots \cdots \cdots \cdots
\end{gathered}
$$

である、ただし， $x_{t}=E_{o} a / A_{1} P_{s}$ である。

(iv) $t=t_{t}$ では，ピストンは無負荷となり，上方 に移動するが，その場合は次式のように運動する。

$$
\delta=-\frac{K_{v} I}{A_{1}{ }^{3}+A_{2}{ }^{3}} \sqrt{A_{2} P_{s}}\left(t-t_{t}\right)+\delta_{t}
$$

一連の制御動作に加えて, $\delta \leqq 0 の$ 適当な点で, シリン ダに対する停止信号（ $i=0$ とする）をリミットスイッ チで与える. 以上によって，作動の1サイクルが終る。 式(13)において重力と摩擦力を含んだ形 $(F-M g$ $\left.\pm F_{c}\right)$ を用いても, 式はやや複雑になるが, 同様の結 果が得られる。すなわち, 部材には $a$ の残留変位が生 じる.

\section{4. 実験およひ考察}

4 ・1 实験システムの權成およひ実験方法 200 トン油压プレスを用いて行った実験結果を以下に示す (図 4 参照)。制御はマイクロコンピュータによって行 われ、プログラム言語はアセンブリ言語と BASICか ら成る。

アクチュエータはサーボ弁, 油圧シリンダから構成 される.サーボ弁の定格流量 $83.3 \times 10^{-6}\left(\mathrm{~m}^{3} / \mathrm{s}\right)(\triangle P=$ $6.87(\mathrm{MPa})$ 時), 使用压力 $15.7(\mathrm{MPa})$, 定格電流 $30[\mathrm{~mA}]$ である. シリンダの内径, ロッド径, ストロー クは，それぞれ 0.4[m]，0.22[m]，0.6[m]である。

荷重は油压シリンダのヘッド圧力とロッド压力の検 出により算出する。压力の検出はひずみゲージ式の压 力変換器を用いており，0〜49[MPa]の測定範用を 0 $\sim 5[\mathrm{~V}]$ の電圧に変換する．直線度は $0.3 \%$ である。管 曲り下端部の変位をダイヤルダージにより検出し、ア

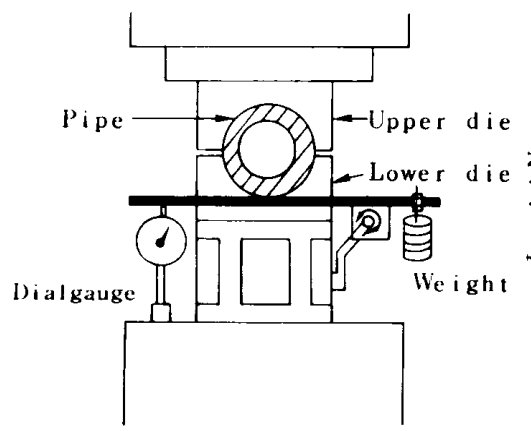

図 7 変位計測のモデル図

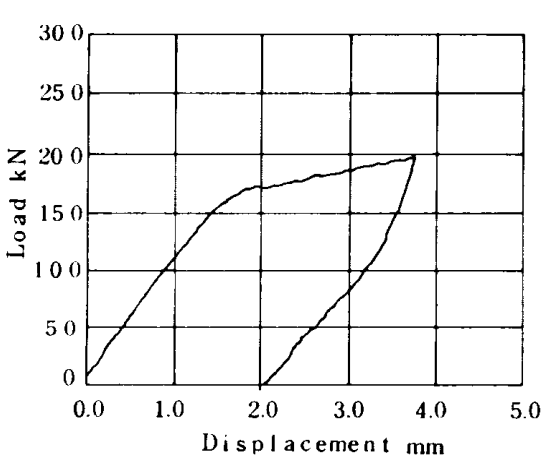

図 8 パイプ稪正実験結果（その1）

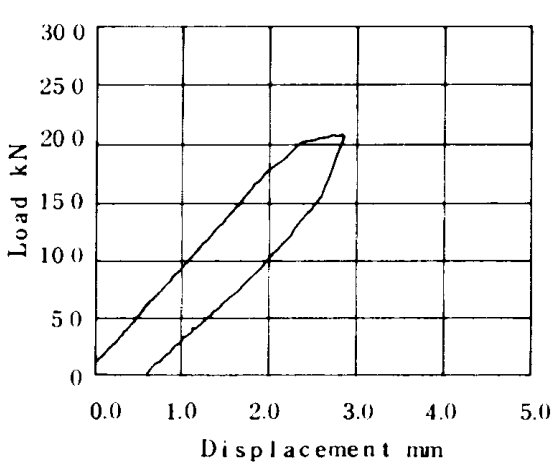

図 9 パイブ看正実験結果（その2） 
表 1 実験条件

\begin{tabular}{|c|c|c|c|c|c|c|}
\hline $\begin{array}{c}\text { Work piece } \\
\text { No. }\end{array}$ & $\begin{array}{c}\text { Outside diameter } \\
\text { Do }\end{array}$ & $\underset{\mathrm{t}}{\text { Pipe thickness }}$ & $\begin{array}{c}\text { Span length } \\
\ell \quad \mathrm{mm}\end{array}$ & Theory of Eo & $\begin{array}{c}\text { Number of } \\
\text { times }\end{array}$ & $\begin{array}{l}\text { Reference } \delta \mathrm{r} \\
\text { displacement } \mathrm{mm}\end{array}$ \\
\hline (1) & 73 & 5.51 & 400 & $105 \times 10^{7}$ & 11 & $0.10 \sim 200$ \\
\hline (2) & 127 & 450 & 870 & 50 & 5 & $0.10 \sim 100$ \\
\hline (3) & 73 & 701 & 400 & 126 & 10 & $010-200$ \\
\hline (4) & 127 & 900 & 870 & 89 & 5 & $010-100$ \\
\hline (5) & 73 & 900 & 400 & 149 & 12 & $0.10-200$ \\
\hline (6) & 73 & 516 & 400 & 100 & 10 & $0.10 \sim 200$ \\
\hline
\end{tabular}

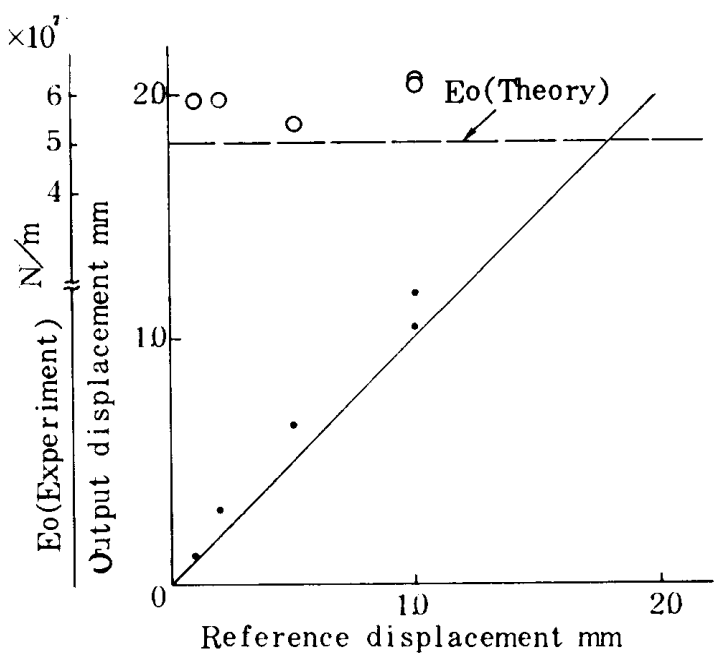

図 10 部材 (2)の実験結果
ナログ電圧に変換する（図 7 参照)。

鋼管を曲げるときの運動方程式は，微速で駆動し， 矯正変位も微小となることから, 慣性力 $(M \dot{v})$ が無視 でき, 次のようになる。

$$
F=A_{1} P_{1}-A_{2} P_{2}+M g-\operatorname{sgn}(v) \cdot F_{c}
$$

ただし, $A_{1}: 0.1257\left[\mathrm{~m}^{2}\right], A_{2}: 0.0877\left(\mathrm{~m}^{2}\right]$ である。

重力 $(M g)$ および摩擦力 $\left[\operatorname{sgn}(v) \cdot F_{c}\right]$ は微速駆動の 簀囲ではほほ一定とみなせ, 無負荷で駆動したときの 実験結果は，下降時（負荷時）に $2.06 \times 10^{4}[\mathrm{~N}]$, 上昇時 (除荷時) に $5.69 \times 10^{4}[\mathrm{~N}]$ となった。これらの值を式 (25)に代入し， $P_{1}, P_{2}$ を圧力変換器によって計測する ことによって，Fをリアルタイムで求めた。このとき， 圧力值はノイズ分を除去するため 50 回測定して単純 平均した值を測定結果とした。るそのため演算時間は $0.31[\mathrm{~s}]$ であった。

実験に用いた部材はSTKM13A（JISG 3444, 引張 応力 $38 \mathrm{kgf} / \mathrm{mm}^{2}$ 以上), STO-J (JISG 3439, 引張応 力 $53 \mathrm{kgf} / \mathrm{mm}^{2}$ 以上）で，矯正変位計測を容易にする ため，ストレート管（全長 $1.2(\mathrm{~m})$ に対して微小曲げ実 験を行った。実験条件を表 1 に示す.表 1 において, 部 材 (2)，(4)，(5)，(6)はSTKM13A，部材 (1)， ( 3 ) は STO-Jである.

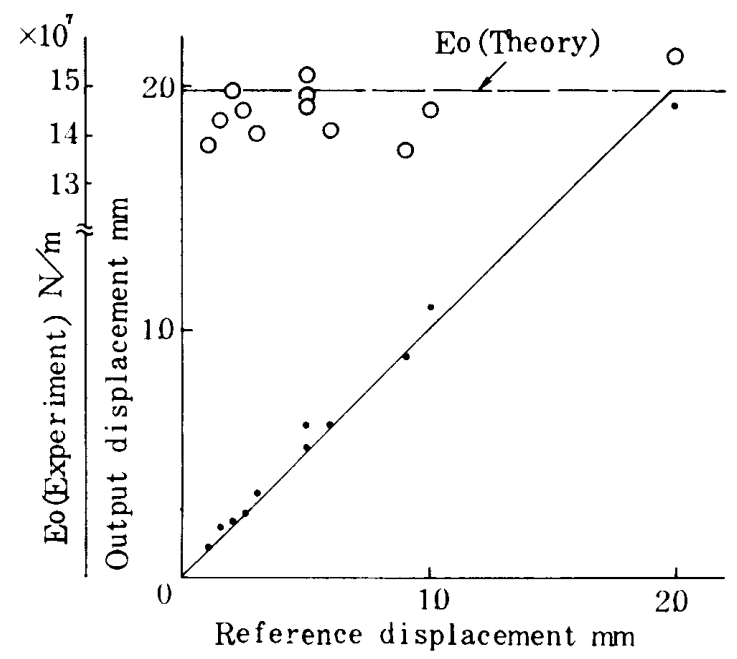

図 11 部材 $(5)$ の実験結果

$4 \cdot 2$ 実験結果およひ考察＼cjkstart変位と荷重変化の関 係の例を図 8,9 に示す. 図 8 は部材 (1)で目標值が $2.0 \mathrm{~mm}$ の場合で, 実験結果は $2.0 \mathrm{~mm}$, 図 9 は部材 (4)で目標值が $0.50 \mathrm{~mm}$ の場合で, 実験結果は 0.62 $\mathrm{mm}$ である。これらの記録からみて，2 章で述べた弾 塑性モデルが適切なものであったことがわかる。

目標値と測定值を比較した結果について，部材 (2) と（5)の例を図 10,11 に示す. 目標値は図中のこう配 $45^{\circ}$ の直線である. 平均的に測定值は目標値よりも大 きな值となっているが, 実験を行ったすべての部材に おいて目標値に十分近い結果が得られている. 目標値 と測定值との差は，その絶刘值が目標値の大きさによ らないことが特徵である、実験を行った資料全体につ いての標準偏差 $\sigma$ を求めると, $\sigma=0.0844 \mathrm{~mm}$ であ る.また $\max \left|a-\delta_{t}\right|$ は $0.18 \mathrm{~mm}$ であった。これらの 值はもちろん鋼管稪正としては，十分満足できるもの である。

図 10，11には制御則において $\delta$ を求めるために用 いた $E_{o}$ の測定值と $E_{o}$ の理論值 $\left(48 E I / \ell^{3}\right)$ の比も示 してある.支点の条件によって測定值は変化するが, 制御系の中では $E_{o}$ をオンライン測定するために，目 標值と測定値との差 $\left(\alpha-\delta_{t}\right)$ は常に安定して小さな值 


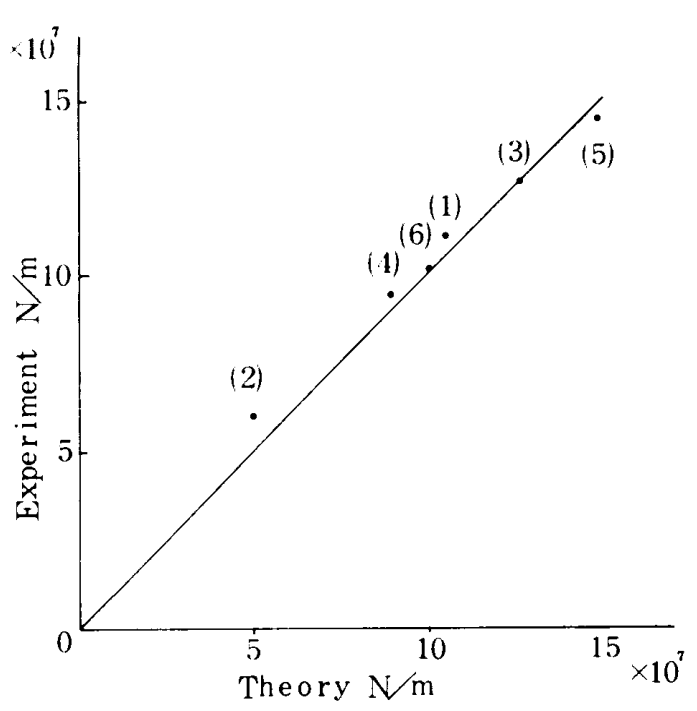

図 $12 E_{o}$ の理論値と測定值 (平均值) の関係

とすることができた。

各部材の測定值ごとに $E_{o}$ を平均して示すと, 図 12 を得る。この結果はかなり理論值と良い一致を示して いるといえる，Eoの值は，反力を推定したり，油圧系 の出力を決定するときにも必要であるが， $E_{o}$ の理論 值により十分実用的な推定ができるといえる.図 10 , 11 に戻り，各々の実験での $E_{o}$ の測定値を見ると，理 論値に対して上下にばらついている。このばらつきは，
ランタムであることから，鋼管断面のだ円度，クラン プ金型と鋼管との当たりの良し悪しなどの，二次的要 因によるものと考えられる，F- $\delta$ 曲線の負荷時 $\left(E_{o}\right)$ と除荷時 $\left(E_{o}^{\prime}\right)$ のこう配は颜密には平行でないが, 本 制御方法を実験に適用した結果から，稪正変位の精度 としては無視できることがわかった。

\section{5. 結}

本論文では，鋼管管端部の曲り矯正について，材料 特性に依存せずスプリングバック量を補償した自動矯 正制御方法を考案した。プレス用大形油圧シリンダを 用いて，目標矯正変位を $0.1 \sim 2.0 \mathrm{~mm}$ として実験を行 ったところ，0.18 $\mathrm{mm}$ 以内の精度ですべて䂑正するこ とができ，優れた制御方法であることを実証した，本 制御方法は，微小曲げであれば，板の適応曲げ方法に も適用可能であると思われる。

\section{文献}

（1）杉森・注か5名, 鉄と銅.73-4 (1987), 304.

(2) Stelson, K. A and Gossard, D. C., Trans. ASME. J. Eng. Ind., 104 (1982), 389.

(3) Hardt, D. E. and Chen, B., Trans. ASME, J. Eng. Ind. 107 (1985), 141.

(4) Hardt, D. E.. Roberts. M. A. and Stelson. K. A., Trans. ASME, J. Dyn. Syst. Meas. Control, 104 (1982), 317. 